\title{
Inheritance of a Chlorophyll Deficiency in Hazelnut
}

Shawn A. Mehlenbacher and Maxine M. Thompson

Department of Horticulture, 2042 Cordley Hall, Oregon State University, Corvallis, OR 97331-2911

Additional index words. Corylus avellana, filbert, anthocyanin

Abstract. A chlorophyll deficiency expressed as yellowing of leaves was observed in hazelnut (Corylus avellana L.) progenies. Segregation ratios approximated 3 green : 1 yellow, indicating control by a single recessive gene designated chlorophyll deficient \#1, for which the symbol c, is proposed. 'Barcelona', 'Butler', 'Compton', 'Lansing', Willamette', and the ornamental selection 'Redleaf \#3' are heterozygous. Pedigree analysis strongly suggests that all heteroxygotes inherited the recessive allele from 'Barcelona'. A cross of 'Barcelona' with the yellow-leafed ornamental Corylus avellana L. var. aurea Kirchn. produced no yellow-leafed seedlings, indicating that the chlorophyll deficiencies from these two sources are controlled by different loci. Progenies segregating simultaneously for this trait and the gene controlling presence of anthocyanin indicated that the two traits are inherited independently. Seedlings deficient in chlorophyll but with anthocyanin were able to survive under field conditions, while leaves of yellow-leafed seedlings lacking anthocyanin became scorched and the trees died.

Chlorophyll deficiencies commonly segregate in progenies of naturally cross-pollinated and clonally propagated plants and may be expressed as striped, variegated, albino,

Received for publication 15 Feb. 1991. Oregon Agricultural Experiment Station Technical Paper no. 9346. This research was supported with funds from the Oregon Hazelnut Commission. We thank David C. Smith and Loretta K. Brenner for technical assistance. The cost of publishing this paper was defrayed in part by the payment of page charges. Under postal regulations, this paper therefore must be hereby marked advertisement solely to indicate this fact. yellow, yellow-green, or pale-green leaves. Chlorophyll deficiencies are often lethal or sublethal and are generally monogenic recessives. Many such mutants have been described in maize (Neuffer et al., 1968). Among the tree fruits, albinos have been reported in apple (Brown, 1975; Hall and Crane, 1933), peach (Bailey and French, 1941), and sweet cherry (Kerr, 1963). Klein et al. (1963) reported that 13 of 20 apple genotypes studied were heterozygous for a pale-green lethal. In this paper, we describe a monogenic recessive chlorophyll deficiency in seedlings of 'Barcelona' hazelnut and demonstrate that it is inherited independently of the presence 
Table 1. Segregation for green and yellow leaf color in hazelnut crosses.

\begin{tabular}{|c|c|c|c|c|c|}
\hline \multirow[b]{2}{*}{ Progeny code } & \multirow[b]{2}{*}{ Parentagey } & \multicolumn{2}{|c|}{ No. plants } & \multicolumn{2}{|c|}{$x^{2}(3: 1$ ratio $)$} \\
\hline & & Green & Yellow & Valuc & $P$ \\
\hline 77026 & $013.019 \times$ Butler & 58 & 31 & 4.59 & 0.03 \\
\hline 77031 & $014.002 \times$ Barcelona & 11 & 4 & 0.02 & 0.9 \\
\hline 77039 & $018.009 \times$ Butler & 66 & 17 & 0.90 & $0.3-0.4$ \\
\hline 77060 & $026.020 \times 014.002$ & 114 & 34 & 0.32 & $0.5-0.6$ \\
\hline 77067 & Barcelona $\times 014.002$ & 47 & 18 & 0.25 & 0.6 \\
\hline 77068 & Barcelona $\times$ Butler & 105 & 23 & 3.38 & $0.05-0.1$ \\
\hline 86002 & Barcelona $\times 017.068$ & 31 & 10 & 0.01 & $0.9-0.95$ \\
\hline 89007 & Willamette $x$ self & 43 & 11 & 0.62 & $0.4-0.5$ \\
\hline 89010 & $220.013 \times$ Hend $3-70$ & 33 & 8 & 0.66 & $0.4-0.5$ \\
\hline 89068 & $231.111 \times 226.122$ & 408 & 121 & 1.28 & $0.2-0.3$ \\
\hline 89071 & $244.001 \times$ Hend $3-70$ & 162 & 48 & 0.51 & $0.4-0.5$ \\
\hline Pooled data & & 1078 & 325 & 2.52 & $0.1 \multimap 0.2$ \\
\hline Hetcrogeneity & & & & 10.02 & $0.2-0.3$ \\
\hline
\end{tabular}

The first two digits of the progeny code indicate the year of the cross and the last three digits, the number of the cross.

${ }^{y}$ Numbered selections from the Oregon State Univ. breeding program are listed by location of the original seedling tree (row number.tree number).

of anthocyanin and not allelic to the chlorophyll deficiency found in Corylus avellana var. aurea.

The progenies studied were produced from controlled crosses as part of a hazelnut breeding program. Following stratification for 3 to 4 months at $\approx 4 \mathrm{C}$, seeds were planted in flats in the greenhouse. Progenies segregating for leaf color were noted and segregation ratios were scored 5 to 6 weeks after planting. Chi-square goodness-of-fit tests were performed for an expected ratio of 3 green : 1 yellow. For progenies segregating simultaneously for the chlorophyll deficiency and the presence of anthocyanin, ratios were tested separately for each trait, and a goodness-offit test to a combined 3 red : 3 green : 1 redyellow : 1 yellow ratio was performed. A contingency chi-square test was used to detect deviations from expectations based on independent assortment.

Whereas 10 of the 11 progenies fit a 3 green : 1 yellow segregation expected for a single recessive gene, progeny 77026 had a surplus of yellow-leafed seedlings (Table 1). We propose the symbol $c_{1}$ for this gene, designated chlorophyll deficient \#1 to indicate that it is the first such gene reported in hazelnut.

Pedigrees of parents segregating for yellow leaves were examined to determine if heterozygotes had a common ancestor (Table
2). 'Barcelona' is heterozygous $\left(C_{l} c_{l}\right)$ and transmitted the $\mathrm{c}$, allele to many of its offspring. Other heterozygotes include 'Butler', 'Compton', and 'Lansing \#1', grower selections that originated in Oregon, where 'Barcelona' is the leading cultivar and 'Daviana' the leading pollinizer. All three have long been suspected of being hybrids between 'Barcelona' and 'Daviana', as they are morphologically very similar to seedlings resulting from the controlled cross. Analysis of incompatibility alleles has shown that each has one allele in common with 'Barcelona' $\left(S_{1} S_{2}\right)$ and $S_{3}$ in common with 'Daviana' (Mehlenbacher and Thompson, 1988). It is very likely that the three grower selections inherited the yellow-leaf allele from 'Barcelona'. Twenty-one numbered selections and the new cultivar Willamette, a seedling from the cross 'Montebello' $\times$ 'Compton', are also heterozygous. In all cases, pedigrees indicate that heterozygotes inherited the chlorophyll-deficient allele either directly from 'Barcelona' or indirectly through one of the grower selections noted.

A cross of 'Barcelona' with C. avellana var. aurea, the yellow-leafed ornamental 'Goldhasel' described by Goeschke (1887), produced 94 seedlings. All of them had green leaves, indicating that the two chlorophyll deficiencies are controlled by different loci. This result is consistent with the differences in chlo-
Table 2. Pedigrees of selections heterozygous at the chlorophyll deficient \#1 locus ${ }^{\mathrm{z}}$

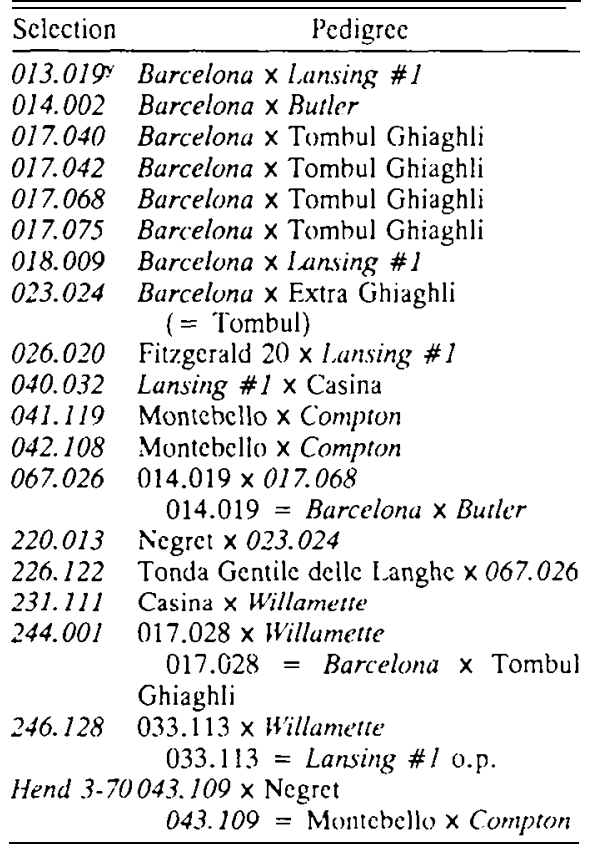

${ }^{\mathrm{z}}$ Genotypes known to be heterozygous are in italics.

${ }^{\mathrm{y}}$ Numbered selections from the Oregon State Univ. breeding program are listed by location of the original seedling tree (row number.tree number).

rophyll content and spectra of intact leaves previously reported (Daley et al., 1986). The two mutants also differ in appearance. Yellowleafed seedlings of 'Barcelona' are bright yellow but can be maintained in the greenhouse. Upon transplanting to the field, leaves become scorched and trees die. By contrast, trees of C. avellana var. aurea survive in the field and leaf color varies with position. Leaves at the top of the canopy, where they are exposed to the sun, are bright yellow. The leaves are yellowish-green $50 \mathrm{~cm}$ below the canopy surface, and inside the tree, leaves are nearly normal in color. The inheritance of the chlorophyll deficiency in C. avellana var. aurea still needs to be determined.

When the ornamental selection 'Redleaf \#3' was crossed with three heterozygous $\left(C_{l} c_{1}\right)$ green-leafed selections, simultaneous segregation for the presence of anthocyanin and chlorophyll deficiency was noted (Table

Table 3. Progenies segregating simultaneously for chlorophyll deficiency and presence of anthocyanin.

\begin{tabular}{|c|c|c|c|c|c|c|c|c|c|c|c|c|c|}
\hline \multirow[b]{3}{*}{ Progeny coder } & \multirow[b]{3}{*}{ Parentagey } & \multicolumn{4}{|c|}{ No. plants } & \multicolumn{8}{|c|}{$x^{2}$} \\
\hline & & \multicolumn{2}{|c|}{ Green } & \multicolumn{2}{|c|}{ Ycllow } & \multicolumn{2}{|c|}{$3: 1^{x}$} & \multicolumn{2}{|c|}{$1: 1^{\mathrm{w}}$} & \multicolumn{2}{|c|}{$3: 3: 1: 1^{v}$} & \multicolumn{2}{|c|}{ Indep. ${ }^{4}$} \\
\hline & & $\overline{\operatorname{Red}}$ & Nonred & $\overline{\mathrm{Red}}$ & $\overline{\text { Nonred }}$ & Value & $P$ & Value & $P$ & Value & $P$ & Value & $P$ \\
\hline 87072 & $040.032 \times$ Redleaf \#3 & 13 & 11 & 4 & 4 & 0.0 & 1.0 & 0.13 & $0.7-0.8$ & 0.17 & $0.95-0.99$ & 0.04 & $0.8-0.9$ \\
\hline 87071 & $017.075 \times$ Redleaf \#3 & 41 & 27 & 5 & 7 & 4.27 & 0.04 & 1.8 & $0.1-0.2$ & 7.73 & $0.05-0.1$ & 1.45 & $0.2-0.3$ \\
\hline 89102 & $017.075 \times$ Redlcaf \# 3 & 53 & 41 & 14 & 19 & 0.07 & $0.7-0.8$ & 0.39 & $0.5-0.6$ & 2.36 & 0.5 & 1.50 & $0.2-0.3$ \\
\hline 89103 & Rcdlcaf \#3 x 017.075 & 48 & 42 & 8 & 13 & 2.19 & $0.3-0.4$ & 0.01 & $0.5-0.6$ & 3.53 & $0.3-0.4$ & 1.42 & $0.2-0.3$ \\
\hline 89104 & Redlcaf \#3 x 246.128 & 26 & 25 & 4 & 6 & 2.41 & $0.1-0.2$ & 0.02 & $0.8-0.9$ & 2.70 & $0.4-0.5$ & 0.40 & $0.5-0.6$ \\
\hline Pooled data & & 181 & 146 & 35 & 49 & 4.56 & 0.04 & 1.07 & 0.3 & 10.44 & $<0.005$ & 1.22 & $0.2-0.3$ \\
\hline Heterogencity & & & & & & 4.38 & $0.3-0.4$ & 1.28 & $0.8-0.9$ & 6.05 & $0.1-0.2$ & 3.59 & $0.4-0.5$ \\
\hline
\end{tabular}

${ }^{\mathrm{z}}$ The first two digits of the progeny code indicate the year of the cross and the last three digits the number of the cross.

${ }^{\mathrm{y}}$ Numbered selections from the Oregon State Univ. breeding program arc listed by location of the original seedling tree (row number.tree number).

${ }^{\mathrm{x}}$ Expected ratio 3 green : 1 yellow.

${ }^{\mathrm{w}}$ Expected ratio 1 red : nonred.

${ }^{v}$ Expected ratio 3 red : 3 green : 1 red-yellow : 1 yellow.

"Contingency test for independence. 
2). All five progenies fit the ratio of 1 with anthocyanin : 1 without. This result is consistent with those of Thompson (1985), who demonstrated that in crosses of green-leafed cultivars with the red-leafed 'Rode Zeller' and $C$. avellana var. fusco rubra Dippel, the presence of anthocyanin is conferred by a single dominant gene. 'Redleaf \#3', the parent of the progenies listed in Table 3 , is an open-pollinated seedling of 'Barcelona', and morphological traits indicate that 'Rode Zeller' was the pollen parent. 'Redleaf \#3', like 'Rode Zeller', is heterozygous for the dominant gene for leaf anthocyanin. Four of the five progenies fit the expected ratio of 3 green (or red-green) : 1 yellow (or red-yellow), but progency 87071 had such a deficiency of yellow-leafed seedlings that it caused the pooled data from all five progenies to also show this deficiency. There is also a slight deficiency of yellow-leafed seedlings in the pooled data from crosses segregating only for this trait (Table 1), but it is not as striking as in Table 2. The five progenies also fit a combined segregation ratio of 3 red : 3 green : 1 red-yellow : 1 yellow, although the pooled data showed a significant deviation from the expected ratio due to deficiencies of green and red-yellow seedlings. Deficiencies of these two phenotypes were present in all progenies. Contingency chi squares showed independence of chlorophyll deficiency and presence of anthocyanin.

Seedlings that are homozygous $c_{1} c_{1}$ and have anthocyanin pigment were grown in pots in the greenhouse in Summer 1988 and transplanted to the field in the fall. Although the seedlings are smaller than their greenand red-leafed siblings, they are surviving. Apparently the anthocyanin pigment offers protection and prevents scorching of the leaves.

\section{Literature Cited}

Bailey, J.S. and A.P. French. 1941. The genetic composition of peaches. Massachusetts Agr. Expt. Sta. Bui. 378:91.

Brown, A.G. 1975. Apples, p. 3-37. In: J. Janick and J.N. Moore (eds.). Advances in fruit breeding. Purdue Univ. Press, West Lafayette, Ind.

Daley, L.S., M.M. Thompson, W.M. Proebsting, J. Postman, and B.R. Jeong. 1986. Use of fourthderivative visible spectoscopy of leaf lamina in plant germplasm characterization. Spectroscopy $1(7): 28-31$

Goeschke, F. 1887. Die Haselnuss, ihre Arten und ihre Kultur. Paul Parey, Berlin.

Hail, A.D. and M.B. Crane. 1933. The apple. Martin Hopkinson, London.

Kerr, E.A. 1963. Inheritance of crinkle, variegation and albinism in sweet cherry. Can. J. Bot. 41:1395-1404.

Klein, L.G., R.D. Way, and R.D. Lamb. 1963. The inheritance of a lethal factor in apples. Proc. Amer. Soc. Hort. Sci. 77:50-53.

Mehlenbacher, S.A. and M.M. Thompson. 1988. Dominance relationships among S-alleles in Corylus avellana L. Theor. Appl. Genet. 76:669672.

Neuffer, M.G.. L. Jones, and M.S. Zuber. 1968. The mutants of maize. Crop Sci. Soc. Amer., Madison, Wis.

Thompson, M.M. 1985. Linkage of the incompatibility locus and red pigmentation genes in hazelnut. J. Hered. 76:119-122. 